The Canadian Mineralogist

Vol. 42, pp. 169-182 (2004)

\title{
MORPHOLOGICAL AND CHEMICAL STUDY OF PLACER GOLD FROM THE SAN LUIS RANGE, ARGENTINA
}

\author{
María Florencia MÁRQUEZ-ZAVALÍA \\ IANIGLA, CRICYT (CONICET), Bajada del Cerro s/n, Parque Gral. San Martin; C.C.330 (5.500) Mendoza, Argentina
}

GORDON SOUTHAM

Department of Earth Sciences, University of Western Ontario, London, Ontario N6A 5B7, Canada

JAMES R. CRAIGII

Department of Geological Sciences, Virginia Polytechnic Institute and State University, 4044 Derring Hall, Blacksburg, Virginia 24061-0420, U.S.A.

\section{Miguel ANGEl GALLISKI}

IANIGLA, CRICYT (CONICET), Bajada del Cerro s/n, Parque Gral. San Martin; C.C.330 (5.500) Mendoza, Argentina

\begin{abstract}
The composition of placer gold from the San Luis Range, Argentina, is poorly documented, although these deposits have been known since the $18^{\text {th }}$ century. A detailed study of gold grains collected from different streams in the La Carolina gold district was carried out. We performed 502 analyses on 191 grains. The core composition of the gold grains is heterogeneous, with an average chemical composition of 58 to 74 wt. $\% \mathrm{Au}, 25$ to $40 \% \mathrm{Ag}$, up to $0.5 \% \mathrm{Hg}$, and less than $0.4 \% \mathrm{Cu}$. The rim of each grain is generally richer in gold than the core, and the contact between rim and core is very sharp but of irregular shape and complex texture. There are populations with different chemical composition, but the compositional differences among rounded grains and those having a more delicate morphology are not invariably either significant or consistent. All sources are restricted to deposits associated with Tertiary volcanic rocks in the area, and the variable and wide range of fineness points to low-sulfidation epithermal-type deposits as the most likely source. The sharpness of the core-rim contact may result from either electrochemical processes active in the stream or stream sediments, or Au and Ag dissolution processes followed by Au precipitation in surface or near-surface environments. The presence of overgrowths of gold on gold grains suggests that there was secondary precipitation of gold after the host grain was formed. Gold grains do grow in low-temperature geochemical settings, and we believe that their composition becomes more gold-rich as the grains move downstream or are buried in the sediments. Anthropogenic $\mathrm{Hg}$ was detected in some of the streams, and even where there are several sources for it, we believe that all of it is coming from the amalgamation processes used by local inhabitants to recover the panned gold.
\end{abstract}

Keywords: gold grains, gold rims, placer gold deposits, San Luis Range, Argentina.

\section{SOMMAIRE}

On connaît mal la composition de l'or dans les placers aurifères de la chaîne de San Luis, en Argentine, quoique ces gisements sont connus depuis le dix-huitième siècle. Nous présentons les résultats d'une étude détaillée de pépites d'or prélevées de divers cours d'eau du district aurifère de La Carolina. Nous avons effectué 502 analyses sur 191 grains. Le coeur des grains est hétérogène, contenant en moyenne entre 58 et $74 \% \mathrm{Au}, 25$ et $40 \% \mathrm{Ag}$, jusqu'à $0.5 \% \mathrm{Hg}$, et moins de $0.4 \% \mathrm{Cu}$. La bordure de chaque grain est généralement plus riche en or que le coeur, et le contact entre ce liseré et le coeur est très franc, mais aux contours irréguliers et à texture complexe. Nous décelons des populations différant en composition, mais les différences parmi les grains arrondis et ceux ayant une morphologie plus délicate ne sont pas inmanquablement significatives ou conformes. Les sources de minéralisation sont limitées à des gisements associés au volcanisme tertiaire dans la région, mais la pureté de l'or varie beaucoup, de sorte que des gisements de type épithermal à faible sulfuration semblent rendre compte de la provenance. L'allure abrupte du contact entre le coeur et le liseré pourrait résulter de processus électrochimiques dans le cours d'eau ou dans les sédiments qu'ils

E-mail addresses: mzavalia@lab.cricyt.edu.ar, gsoutham@uwo.ca, jrcraig@vt.edu, galliski@lab.cricyt.edu.ar II Present address: QAR Project, c/o IMS, 3431 Arendell Street, Morehead City, North Carolina 28557, U.S.A. 
ont déposés, ou bien d'une dissolution de l'or et de l'argent, suivie de la précipitation de l'or dans un milieu à la surface ou près de la surface. D'après la présence de surcroissances d'or sur des grains d'or, il y aurait eu une précipitation secondaire d'or après la formation du grain principal. Les grains d'or peuvent donc croître dans un milieu géochimique de basse température; nous croyons que la composition devient enrichie en or à mesure que les grains sont transportés dans le cours d'eau ou sont enfouis dans les sédiments. Nous avons décelé des signes de mercure anthropogénique dans certains cours d'eau. Même où il pourrait y avoir plus d'une source du mercure, nous l'attribuons uniquement au processus d'amalgamation utilisé par les habitants locaux intéressés à récupérer l'or exploité à la batée.

(Traduit par la Rédaction)

Mots-clés: grains d'or, liseré d'or, gisements de type placer, chaîne de San Luis, Argentine.

\section{INTRODUCTION}

The chemical composition of placer gold from Argentina is poorly documented in the literature. Several studies have been performed on gold grains in the San Luis area (Burmeister 1934, Bassi 1948, Rosello \& García 1983, Karlsson \& Porta 1991, Guillou \& Cardó 1995, Rosello \& Castro 1995, Castro 1999), but none of them have given much information about the composition of the gold grains, which is one of the main objectives of this paper.

Our main aim in this research was to study the gold grains collected from various streams and, where possible, in different sections of the same stream, in the La Carolina area, San Luis Province, Argentina. We report on our examination of the morphological develoments of the grains, results of our electron-microprobe analyses of different domains of specific grains (border, core, rim and veinlets) for uncontaminated gold grains as well as the ones containing anthropogenic $\mathrm{Hg}$, and an evaluation of the process leading to the formation of the rim, as well as of a possible source-area for the placer gold.

\section{Geological Setting}

The La Carolina district is located in the Departamento Pringles, Provincia de San Luis, Argentina, about $80 \mathrm{~km}$ to the north of the capital of the province. The area of the placer deposits forms part of the Pampean Ranges, consisting of a Precambrian-Paleozoic crystalline basement, Tertiary volcanic rocks, Pliocene gravels and Quaternary cover (Bassi 1948, 1990).

Several authors have studied the geology of the crystalline basement, and it is continuously being updated (e.g., Steenken et al. 2002, and references therein). A comprehensive review of the background information, together with a formal description of the geological units, and new geochronological data was made by Sims et al. (1997, 1998). In the present summary, we will follow their general descriptions.

The La Carolina district (Fig. 1) consists of elongate NNE-SSW-faulted blocks of metamorphic rocks belonging to the Pringles metamorphic complex and the San Luis Formation. The Pringles metamorphic complex gives a $\mathrm{U}-\mathrm{Pb}$ age $c a$. $480 \mathrm{Ma}$; it is formed by pelitic and psammitic gneisses and schists, intruded by mafic and ultramafic lenses. The outcrops of the San Luis Formation form two subparallel belts that consist mainly of slates, phyllites, and metaconglomerates intruded by some scarce I-type tonalites and an S-type granitepegmatite suite with $c a$. $470 \mathrm{Ma} \mathrm{U}-\mathrm{Pb}$ ages. The Miocene-Pliocene San Luis volcanic group forms a northwest-trending belt $c a .80 \mathrm{~km}$ long, that consists of andesitic to trachyandesitic domes, dikes, sills, lava flows, diatremes and minor pyroclastics rocks. The volcanic suite belongs to a high-K calc-alkaline to shoshonitic suite of arc-related magmas, erupted $700 \mathrm{~km}$ inland of the trench in the Pampean ranges, during an episode of flat-slab subduction of the Nazca plate (Kay \& Gordillo 1994, Urbina et al. 1997). The epithermal deposits described in this area (Fig. 1) are related with this volcanism (Bassi 1948, 1990, Márquez-Zavalía \& Galliski 1994, Rosello \& Castro 1995, Urbina et al. 1997), which was followed by sedimentation of the Pliocene gravels and the Quaternary cover that host the placer deposits.

The volcanic effusions delimit the drainage divide, defining catchment basins to the north and south where the placer deposits are situated. Our gold grains come from placer deposits on the southern belt; they are the more important and of higher grade. These placer deposits have been known since pre-Colombian times, and intermittently mined since the last part of the $18^{\text {th }}$ century; they are hosted in the Pliocene gravels and Quaternary cover, overlying the crystalline basement and the volcanic rocks (Rosello \& García 1983). Angelelli (1984) gave a mean of $4 \mathrm{~g} / \mathrm{m}^{3} \mathrm{Au}$ for the richest part of the placer (llampo) and $0.50 \mathrm{~g} / \mathrm{m}^{3} \mathrm{Au}$ for the barren part, with an irregular distribution. The mass of the gold grains is also irregular; the largest reported mass of gold was $700 \mathrm{~g}$.

\section{Materials ANd Methods}

\section{Field site}

The gold grains analyzed come from six different areas (Fig. 1): (1) upstream and (2) downstream of Arroyo Cañada Honda (two and five samples were panned in situ, respectively; the two sampling locations were 
located $22 \mathrm{~km}$ from one another and will be called in this paper 1.CHu and 2.CHd, respectively), (3) upstream and (4) middle stream of Río de La Carpa (two and three samples, respectively, approximately $8 \mathrm{~km}$ between the two sampling locations: 3.LCu and 4.LCm, respectively), (5) upstream Río Grande (5.RGu), in the vicinity of the abandoned La Carolina gold mine gallery (five samples), and (6) middle stream of the creek (6.CPm) that runs through Estancia La Primavera, at the foothills of Cerro de Piedra (two samples).

\section{Sampling}

One hundred and ninety one gold grains were selected from a collection of 19 samples, and 502 electron-microprobe analyses were performed. The 19 samples come from six different locations, as explained above, and each of the samples coming from the same sampling site corresponds to pannings done at the very same place but during different field trips. The grains studied were selected using a quarter method, leading to about $10 \%$ of the sample recovered. This fraction was examined under the binocular stereo microscope, to check whether it covers all the populations present in the sample. The same was done for the shapes; we studied all the grains not selected to see if there was any habit not represented in the quartered sample. In the few cases where that happened, grains were hand-picked and added to the sample to be studied. Multiple grains were mounted in epoxy sections, some with the longer axis horizontal and some vertical, to have a better view of the rim where present. Later, it became clear that there was no difference in the observations performed in horizontally or vertically oriented grains. This mounting process was selected to get all grains exposed; after that, they were cemented in place and then polished in a conventional manner. The $\mathrm{Hg}$-contaminated particles were not removed before the quartering process, so that population would be also included in the samples to be studied.

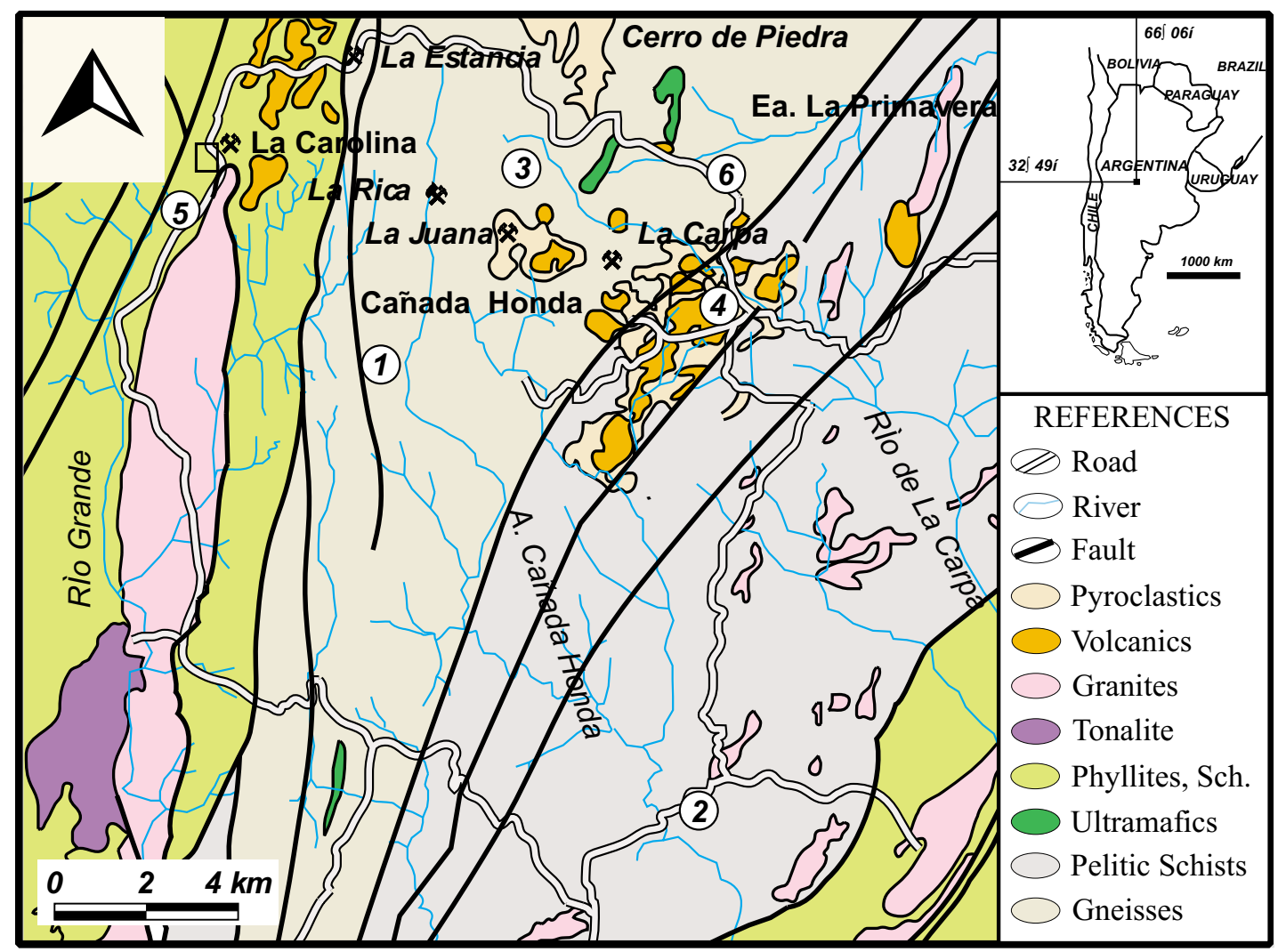

FIG. 1. Geological map modified from Sims et al. (1997). The two greenish yellow belts represent rocks of the San Luis Formation, whereas the greenish gray and gray belts represent gneisses and pelitic schists of the Pringles metamorphic complex, respectively. Numbers represent sampling sites: 1 (1.CHu), 2 (2.CHd), 3 (3.LCu), 4 (4.LCm), 5 (5.RGu) and 6 (6.CPm). 


\section{Analysis of gold grains}

Electron-microprobe analyses were performed in wavelength-dispersion mode using a Cameca SX-50 instrument at the Department of Geological Sciences, University of Manitoba, Winnipeg, Canada. We used a beam diameter of $2 \mu \mathrm{m}$, an acceleration potential of 20 $\mathrm{kV}$, and a sample current of $20 \mathrm{nA}$, measured on a Faraday cup, with counting times of 20 seconds for each element. The following standards were used: $\mathrm{Au}_{100}$ $(\mathrm{Au} M \alpha), \mathrm{Au}_{60} \mathrm{Ag}_{40}(\mathrm{Ag} L \alpha), \mathrm{CuFeS}_{2}(\mathrm{CuK \alpha}), \mathrm{HgTe}$ $(\mathrm{Hg} M \beta)$. The lower limits of detection for $\mathrm{Cu}$ and $\mathrm{Hg}$ are 0.06 and 0.12 wt.\% respectively. Data were reduced using the PAP routine of Pouchou \& Pichoir (1984, 1985).

The analyses were performed on each of the polished grains; we analyzed both core and rim of each grain. In some grains without rim, or with a discontinuous rim, we found that the margin has a different appearance than the rest of the grain; we have analyzed those areas and called them "borders".

The analysis of an unusual, cubic mineral phase observed using conventional techniques was performed using a Hitachi S-4500 field-emission gun scanning electron microscope (FEG-SEM) fully equipped with an $\mathrm{EDAX}^{\mathrm{TM}}$ system. Before energy-dispersion spectroscopy (EDS; EDAX ${ }^{\mathrm{TM}}$ ), the position and "cubic" nature of the grain were confirmed using the back-scatter mode. An area of approximately $100 \mathrm{~nm}^{2}$ in the center of the cubic mineral, and a second region located approximately $5 \mu \mathrm{m}$ into the gold grain from the interface between the cubic mineral and the margin of the gold grain, were analyzed by EDS at an accelerating voltage of $15 \mathrm{kV}$.

\section{Results: Physical Characterization of Gold Grains}

The gold grains have different morphologies (Table 1). Many grains from various sampling sites have crystal (or crystal-like) faces, which presumably represent faces on octahedra of gold, or perhaps in some cases, the inherited imprints from former adjacent minerals.

\section{Arroyo Cañada Honda, upstream (1.Chu)}

The grains are angular and irregular; a rim is generally absent, but where present, it is thin and discontinuous (Fig. 2b) and only slightly darker than the rest of the grain (Fig. 2c). The presence of "rim"-like enrichments in these grains, which are present along fractures inside the grains, is noteworthy (Figs. 2b, c). Also, some of the grains contain several small (approximately 20 $\mu \mathrm{m}$ ) inclusions of galena, quartz, and less abundant, but larger $(100$ to $500 \mu \mathrm{m})$ inclusions of an iron oxyhydroxide. Gold grains of up to $19 \mathrm{~g}$ have been recovered from this site (Sr. Lucero 1996, pers. commun.). An unusual crystal (Fig. 2d) recovered during panning, in the foothills of Cerro Tomolasta, and given to the authors by R. Lianza, has $1.5 \mathrm{~mm}$ distorted $\{111\}$ hopper crystal, similar to some crystals found at Mariposa County, California, U.S.A. (Leicht 1982).

\section{Arroyo Cañada Honda, downstream (2.Chd)}

The gold grains range from rounded grains (Fig. 3a) to folded leaf-like masses (Fig. 3b), flattened grains, to arborescent grains; those arborescent forms are in some cases formed by small crystals "cemented" together

TABLE 1. PHYSICAL CHARACTERIZATION OF GOLD GRAINS, SAN LUIS RANGE, ARGENTINA

\begin{tabular}{|c|c|c|c|c|c|c|c|}
\hline Location & $\#$ & Size $(\mathrm{mm})$ & Shape or Habit & Yellow color & Rim & Inclusions & Coating \\
\hline 1.CHu & 24 & $\begin{array}{l}5 \times 3 \times 3 \text { to } \\
1 \times 0.5 \times 0.5\end{array}$ & Angular, irregular & Pale & Generally absent & Quartz, galena & $\begin{array}{l}\text { Common and } \\
\text { in large patches }\end{array}$ \\
\hline 2.CHd & 44 & $\begin{array}{l}7 \times 6 \times 3 \text { to } \\
2 \times<1 \times<1\end{array}$ & $\begin{array}{l}\text { Round, arborescent, } \\
\text { flat, crystals, leaves, } \\
\text { wires }\end{array}$ & $\begin{array}{l}\text { Dark to } \\
\text { medium }\end{array}$ & Discontinuous & Quartz, pyrite & $\begin{array}{l}\text { Occasional } \\
\text { and thin }\end{array}$ \\
\hline 3. $\mathrm{LCu}$ & 24 & $\begin{array}{l}3 \times 2 \times 2 \text { to } \\
0.5 \times 0.5 \times 0.1\end{array}$ & $\begin{array}{l}\text { Angular, irregular } \gg> \\
\text { arborescent, round }\end{array}$ & Pale to dark & Generally absent & $\begin{array}{l}\text { Quartz } \gg> \\
\text { petzite }\end{array}$ & $\begin{array}{l}\text { Common and in } \\
\text { large patches }\end{array}$ \\
\hline 4.LCm & 18 & $\begin{array}{l}5 \times 3 \times 2 \text { to } \\
<1 \times<1 \times<0.2\end{array}$ & $\begin{array}{l}\text { Irregular, arborescent } \\
>>\text { round, leaves }\end{array}$ & Pale to dark & Discontinuous & Quartz, pyrite & $\begin{array}{l}\text { Omnipresent } \\
\text { and thin }\end{array}$ \\
\hline 5.RGu & 57 & $\begin{array}{l}1 \times 0.5 \times 0.5 \\
\text { to }<0.1\end{array}$ & Irregular (abraded) & Dark & Discontinuous & Quartz & $\begin{array}{l}\text { Occasional } \\
\text { and thin }\end{array}$ \\
\hline 6.CPm & 24 & $\begin{array}{l}2 \times 2 \times 1 \text { to } \\
0.5 \times 0.5 \times 0.2\end{array}$ & $\begin{array}{l}\text { Irregular to round } \\
>>\text { arborescent }\end{array}$ & $\begin{array}{l}\text { Dark to } \\
\text { very dark }\end{array}$ & Discontinuous & Quartz (rare) & $\begin{array}{l}\text { Occasional } \\
\text { and thin }\end{array}$ \\
\hline
\end{tabular}

Sampling sites 1 to 6 are shown in Figure 1. Symbols: CH: Arroyo Cañada Honda; LC: Río de La Carpa; RG: Río Grande; CP: Creek at foothills, Cerro de Piedra; u: upstream; d: downstream; m: middle stream, \#: number of grains studied, Coating: Fe-oxyhydroxide. 
(Fig. 3c). In addition, there are also overgrown crystals of gold on gold leaves (Fig. 3d), wires of gold (Fig. 3e), and crystals (Fig. 3f). In some cases, where small grains of pyrite are associated with gold, a thin coating of iron oxyhydroxide partially covers the gold grains. Several of the smallest gold grains possess a seed-like shape, with an elongate structure but rounded contours. A few of the gold particles enclose some grains of quartz at their margins.

\section{Río de La Carpa, upstream (3.Lcu)}

The grains are mostly angular and irregular; some have a well-developed arborescent habit (Fig. 4a), but rounded contours were also observed. In most cases, the rim is generally absent, but where present, it is discontinuous and has a darker color than the core of the grains. In some cases, the core-rim color relation is inverse; a few grains have both light and dark rims coexisting, and the pale ones are due to $\mathrm{Hg}$ contents in them. In some cases, the rim has a "brain-like" appearance (Fig. 4b) that possesses a high $\mathrm{Hg}$ content (up to $24.87 \%$ and $14.43 \%$ at the rim and core, respectively) presumably remaining from the amalgamation process used locally for the recovering of gold. A few grains contain small inclusions (approximately $100 \mu \mathrm{m}$ ) of quartz crystals (Fig. 4b) and, in one case, we found a small inclusion $(35 \times 15 \mu \mathrm{m})$ of petzite, $\mathrm{Ag}_{3} \mathrm{AuTe}_{2}$. Large patches (up to $400 \mu \mathrm{m}$ ) of an iron oxyhydroxide are common within the grains.

\section{Río de La Carpa, middle stream (4.Lcm)}

The great majority of the grains is irregular, developing an arborescent-like habit (Fig. 5a) and, in some cases, thin leaves (Fig. 5b). Rounded grains are less abundant, but present. The gold grains enclose quartz and pyrite; the grains containing pyrite, almost without exception, have a thin coating of iron oxyhydroxide. Most of the grains have a pale to dark yellow color, commonly with a discontinuous darker rim surrounding them. A few grains possess the brain-like rim, rich in $\mathrm{Hg}$.

\section{Río Grande, upstream (5.Rgu)}

The old La Carolina (Fig. 1) gold mine (gallery mouth) is in the vicinity, upstream from the sampling site. Most of the grains are abraded and irregular, their color in most cases is dark yellow, or pale yellow where $\mathrm{Hg}$-contaminated. In either case, the rim is discontinuous and invariably darker than the core. We note the unusual presence of small (up to $4 \mu \mathrm{m}$ ), cubic $\{100\}$ crystals (Figs. 6a, b), composed of gold (Figs. 6c, d). In some of the grains, the rim has the "brain-like" appearance as described above (Fig. 4b).
Creek that runs through Estancia La Primavera. Middle stream, at the foothills of Cerro de Piedra (6.Cpm)

The grains of gold are generally irregular, but most of them have rounded contours and a few have delicate forms; their color varies from pale to dark and very dark yellow. Most of the grains have a rim, generally discontinuous, and invariably darker yellow in color than the core. In some cases, a "rim" crosses the grain along internal fractures and, in one case, internal patches of similar color to the rim were observed. The thickness of the rim varies from sample to sample, but very seldom is thicker than $25 \mu \mathrm{m}$. A back-scattered electron image of one unusual grain (Fig. 2a) shows an internal and very unusual zonation including a darker "border", which possesses a lower content of gold $(65 \%)$ than the brighter, outer area $(75 \%)$. A few grains are partially tarnished with thin coats of iron oxyhydroxide. Quartz was rarely observed as inclusions in gold. A small subhedral crystal $(0.9 \mathrm{~mm})$ of petzite was found in the gold concentrate.

\section{Composition of Gold Grains}

Five hundred and two analyses of core, rim and border were performed on 191 grains (Table 2). Areas that display different colors and textures on back-scattered electron (BSE) images were also analyzed to evaluate possible chemical trends related to primary sources or to supergene processes. Extensive EDS analyses were made of some grains to check for the presence of elements other than $\mathrm{Au}, \mathrm{Ag}, \mathrm{Cu}$ and $\mathrm{Hg}$, but no additional elements were detected.

The core composition of the gold grains is heterogeneous, and the rim is enriched in gold relative to the core (Tables 2, 3). For the uncontaminated samples (Table 4), i.e., no anthropogenic $\mathrm{Hg}$ (Erasmus et al. 1987), the chemical compositions in the core commonly range between 50 and $83 \mathrm{wt} . \% \mathrm{Au}$ and between 15 and $47 \mathrm{wt} . \% \mathrm{Ag} ; \mathrm{Cu}$ and $\mathrm{Hg}$ values are almost consistently close to the lower limit of detection $(0.06 \mathrm{wt} . \%$ for $\mathrm{Cu}$, $0.12 \mathrm{wt} \%$ for $\mathrm{Hg}$ ) or under it. The anthropogenic $\mathrm{Hg}$ contaminated samples (core, border and rim) give chemical compositions (Table 5) ranging from 54 to 94 wt. $\% \mathrm{Au}, 5$ to $42 \mathrm{wt} . \% \mathrm{Ag}, 2$ to $31 \mathrm{wt} . \% \mathrm{Hg}$, and values for $\mathrm{Cu}$ that are under or very close to the lower limit of detection. Copper, where present, is a minor constituent, with values almost invariably under the lower limit of detection (0.06 wt.\%).

There are some differences, but not significant or consistent in all cases, in the compositions among the diverse morphological populations, except for samples from the Río de La Carpa middle stream (4.LCm). In those samples, the core compositions of the rounded grains have a lower dispersion in their fineness than the 
grains having more delicate morphologies (for simplification, we describe the latter as arborescent in general). The core compositions of the gold grains in samples 4.LCm range between 67 and 77 wt.\% for the arborescent varieties, and between 73 and $76 \mathrm{wt} . \%$ for the populations of rounded grains.

In most of the cases, the rim is richer in gold than the core, but a few grains have an Au-depleted rim. The latter case is especially common, but not limited, to the presence of mercury contamination. Anthropogenic mercury, a remnant from the amalgamation process used in the area, seems to be restricted to samples from Río de La Carpa and Río Grande. Where Hg is present, it is localized primarily along the rim of the gold grains, although two analyses from the core revealed 1.6 and 14.4 wt.\% $\mathrm{Hg}$. Where the mercury contamination reaches values higher than $14 \%$, it corresponds to a pale yellow, "brain-like", spongy crown. When the content in $\mathrm{Hg}$ is lower than $14 \%$, it only affects the color (the higher the $\mathrm{Hg}$ content, the lighter the yellow color), but not the texture of the rim.

One of the gold grains from the 5.RGu sampling site, possessing unusual cubic-section crystals occurring along the margin of the gold grain (Fig. 6a) was examined using back-scattered FEGSEM images (Fig. 6b); these reveal a porous, submicrometric sponge-like structure composed of gold (Fig. 6c), in contrast to the border within the gold grain, which is composed of gold and silver (Fig. 6d).
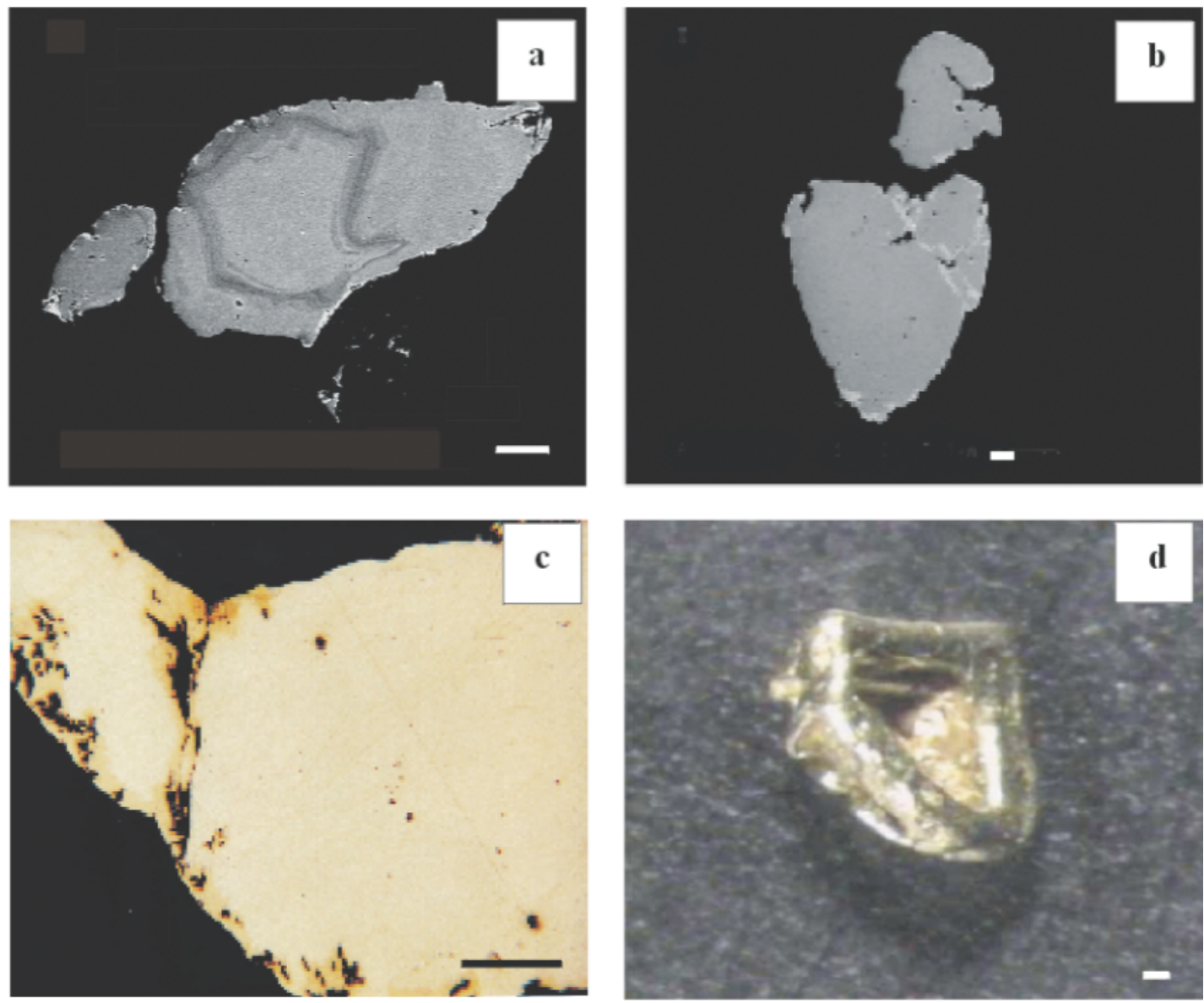

FIG. 2. Typical versus unusual features. SEM back-scattered electron images of gold grains. Scale bar: $100 \mu \mathrm{m}$. (a) From sample site 6.Cpm, grains showing unusual internal zonation: dark area with lower content of gold (65\% $\mathrm{Au}$ ) than the brighter, outer area (75\% Au). (b) Sample site from 1.CHu, possessing the typical, discontinuous rim around the border and internal "rims" along fractures. (c) A reflected-light micrograph (site 2.CHd) of a gold grain containing a common discontinuous rim along the border and fractures. (d) From site 1.CHu, an unusual flattened and distorted hopper crystal of gold. 

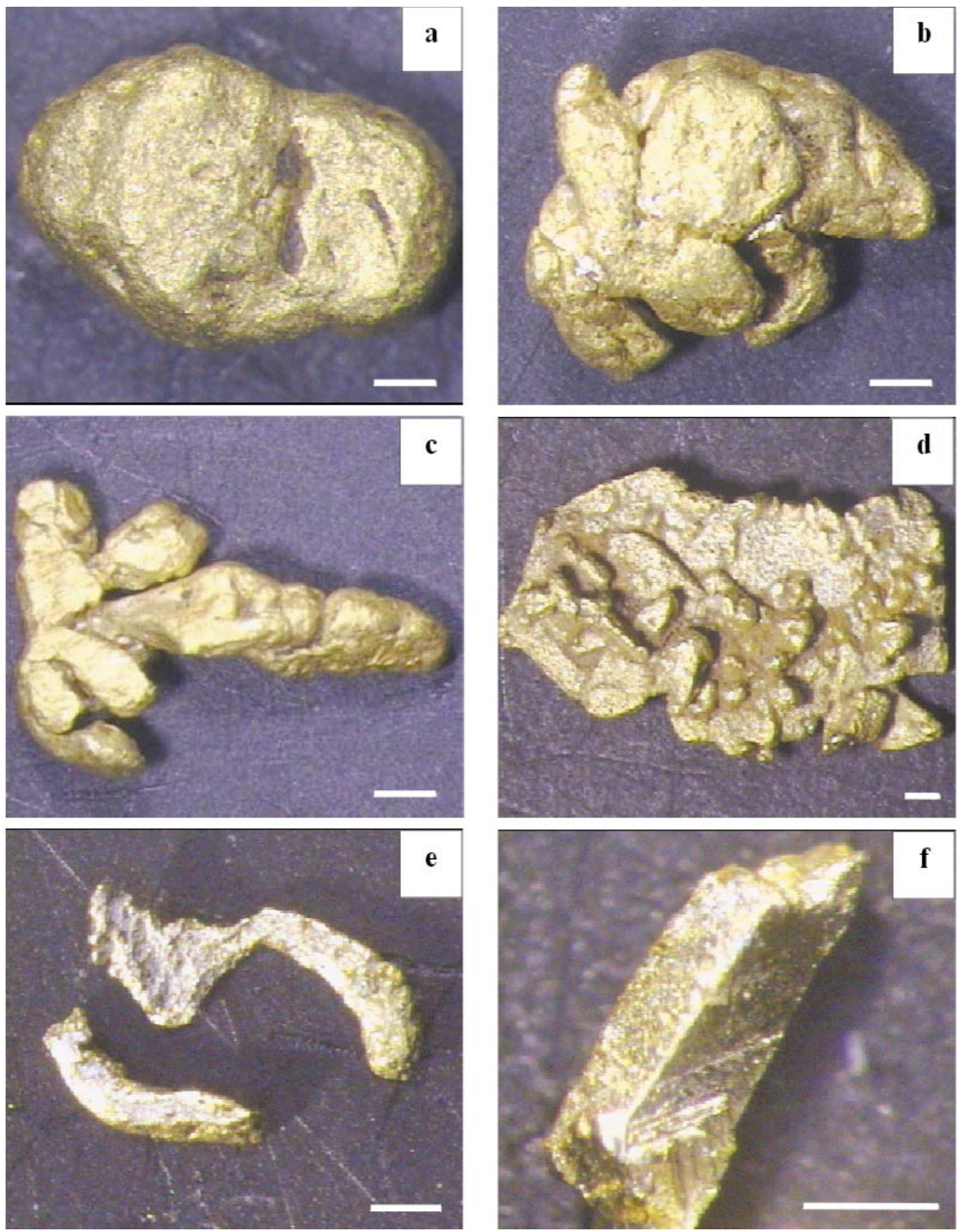

Fig. 3. Typical morphologies of gold grains recovered from the sampling site 2.CHd; scale bar: $300 \mu \mathrm{m}$. (a) Rounded gold grain. (b) Folded leaf of gold, giving the appearance of a rounded gold grain. (c) Slightly rounded arborescent masses of branching distorted octahedra of gold. (d) Leaf of gold with overgrowth of small flattened, distorted octahedra of gold. (e) Wire gold. (f) Gold crystal. 


\section{Discussion}

The sources of placer gold

For several reasons, we suspect that there are multiple sources for the detrital gold encountered in the La Carolina area. Most important is the coexistence at the same sampling site of rounded grains and others that have a more delicate habit (Fig. 2). The delicate nature of the arborescent grains and the ease with which they are deformed in the placer environment suggest that they

TABLE 2. FINENESS OF GOLJ) GRAINS, SAN LUIS RANGI, ARGENTINA

\begin{tabular}{lccccc}
\hline Location & $\begin{array}{c}\text { Fincness range: } \\
\text { core }\end{array}$ & $\begin{array}{c}\text { Fineness runge: } \\
\text { rim }\end{array}$ & $\begin{array}{c}\text { \# core } \\
\text { analyses analyses }\end{array}$ & $\begin{array}{c}\text { fborder } \\
\text { analyses }\end{array}$ \\
\hline 1.CHu & $511-620[579]$ & $865-986[938]$ & 65 & 3 & 11 \\
2.CHd & $536-822[684]$ & $914-1000[965]$ & 83 & 15 & 13 \\
$3 . \mathrm{LCu}$ & $628-809[717]$ & $861-995 \quad[966]$ & 56 & 11 & 6 \\
$4 . \mathrm{LCm}$ & $672-769[739]$ & $969-987 \quad[981]$ & 16 & 3 & 5 \\
$5 . \mathrm{RGu}$ & $523-829[677]$ & $835-1000[929]$ & 86 & 35 & 19 \\
$6 . \mathrm{CP}$ & $604-788[7 / 2]$ & $913-1000 / 972]$ & 44 & 20 & 11
\end{tabular}

Sampling sites 1 to 6 are slown in Figure 1. Symbols: CII: Arroyo Cañada Honda; LC: Río La Carpa; RG: Rio Grande; CP: Creek at foothills Cerro de Piedra; u: upstream; d; downstream; m: middle stream. Values in italic and between brackets correspond to averages. "Border analyses" were peformed where we noted a difference in the appearance at the margins of some rimless grains.

\begin{tabular}{|c|c|c|c|c|c|c|}
\hline $\begin{array}{l}\text { ation } \\
\text { a }\end{array}$ & $\begin{array}{l}\text { 1.CHu } \\
\text { Core }\end{array}$ & $\begin{array}{l}\text { 1. CHu } \\
\text { Rim }\end{array}$ & $\begin{array}{l}\text { 2.CHd } \\
\text { Core }\end{array}$ & $\begin{array}{l}\text { 2.CIId } \\
\text { Rim }\end{array}$ & $\begin{array}{l}\text { 3.LCu } \\
\text { Core }\end{array}$ & $\begin{array}{l}\text { 3.LCu } \\
\text { Rim }\end{array}$ \\
\hline wt. $\%$ & $\begin{array}{r}60.68 \\
39.07 \\
0.06 \\
0.00\end{array}$ & $\begin{array}{r}98.56 \\
1.28 \\
0.04 \\
0.09\end{array}$ & $\begin{array}{r}74.34 \\
25.20 \\
0.06 \\
0.00\end{array}$ & $\begin{array}{r}99.53 \\
0.10 \\
0.03 \\
0.00\end{array}$ & $\begin{array}{r}71.83 \\
27.83 \\
0.00 \\
0.00\end{array}$ & $\begin{array}{r}98.65 \\
1.00 \\
0.06 \\
0.20\end{array}$ \\
\hline & 99.81 & 99.97 & 99.60 & 99.66 & 99.66 & 99.91 \\
\hline 1 atom $\%$ & $\begin{array}{l}0.46 \\
0.54 \\
0.00 \\
0.00\end{array}$ & $\begin{array}{l}0.79 \\
0.21 \\
0.00 \\
0.00\end{array}$ & $\begin{array}{l}0.62 \\
0.38 \\
0.00 \\
0.00\end{array}$ & $\begin{array}{l}0.96 \\
0.04 \\
0.00 \\
0.00\end{array}$ & $\begin{array}{l}0.59 \\
0.41 \\
0.00 \\
0.00\end{array}$ & $\begin{array}{l}0.93 \\
0.07 \\
0.00 \\
0.00\end{array}$ \\
\hline $\begin{array}{l}\text { cation } \\
\text { ea }\end{array}$ & $\begin{array}{l}\text { 4. } \mathrm{LCm} \\
\text { Core }\end{array}$ & $\begin{array}{l}\text { 4.ICm } \\
\text { Rim }\end{array}$ & $\begin{array}{l}\text { 5.RGu } \\
\text { Core }\end{array}$ & $\begin{array}{l}\text { 5.RGu } \\
\text { Rim }\end{array}$ & $\begin{array}{l}\text { 6.CPm } \\
\text { Core }\end{array}$ & $\begin{array}{l}\text { 6.CPm } \\
\text { Rim }\end{array}$ \\
\hline & $\begin{array}{r}75.78 \\
23.38 \\
0.01 \\
0.00\end{array}$ & $\begin{array}{r}98.74 \\
0.49 \\
0.07 \\
0.00\end{array}$ & $\begin{array}{r}69.22 \\
30.39 \\
0.04 \\
0.05\end{array}$ & $\begin{array}{r}98.10 \\
1.76 \\
0.06 \\
0.00\end{array}$ & $\begin{array}{r}77.93 \\
21.50 \\
0.00 \\
0.00\end{array}$ & $\begin{array}{r}98.56 \\
0.79 \\
0.00 \\
0.00\end{array}$ \\
\hline & 99.17 & 99.30 & 99.70 & 99.92 & 99.43 & 99.35 \\
\hline 1 atom $\%$ & $\begin{array}{l}0.64 \\
0.36 \\
0.00 \\
0.00\end{array}$ & $\begin{array}{l}0.99 \\
0.01 \\
0.00 \\
0.00\end{array}$ & $\begin{array}{l}0.56 \\
0.44 \\
0.00 \\
0.00\end{array}$ & $\begin{array}{l}0.97 \\
0.03 \\
0.00 \\
0.00\end{array}$ & $\begin{array}{l}0.66 \\
0.34 \\
0.00 \\
0.00\end{array}$ & $\begin{array}{l}0.99 \\
0.01 \\
0.00 \\
0.00\end{array}$ \\
\hline
\end{tabular}

Sampling sites 1 to 6 are shown in Figure 1. Symbols: CH: Arroyo Cañada Honda: IC. Río de La Carn: RG: Río Giande; $C P$. Creek at foothills, Cerro de Piedra; upstream; d: downstream; $m$ : middle stream. may come from a source closer than either the rounded grains or the associated folded leaves. Supporting this interpretation is the coexistence of families of grains with different core compositions at the same sampling site, which also suggests multiple sources of the gold

\begin{tabular}{|c|c|c|c|c|c|c|c|c|c|c|}
\hline \multirow[t]{2}{*}{ Site } & \multirow[t]{2}{*}{ Filem. } & \multicolumn{3}{|c|}{ Core } & \multicolumn{3}{|c|}{ Border } & \multicolumn{3}{|c|}{ Rim } \\
\hline & & Max. & Min. & Av. & Max. & Min. & Av. & Max. & Min. & Av. \\
\hline 1.Chu & $\begin{array}{l}\mathrm{Au} \\
\mathrm{Ag} \\
\mathrm{Cu} \\
\mathrm{Hg}\end{array}$ & $\begin{array}{r}61.98 \\
47.00 \\
0.11 \\
0.20\end{array}$ & $\begin{array}{r}51.15 \\
36.44 \\
0.00 \\
0.00\end{array}$ & $\begin{array}{r}57.88 \\
40.37 \\
0.04 \\
0.02\end{array}$ & $\begin{array}{r}60.94 \\
46.14 \\
0.05 \\
0.13\end{array}$ & $\begin{array}{c}51.15 \\
36.27 \\
0.00 \\
0.00\end{array}$ & $\begin{array}{r}58.23 \\
39.43 \\
0.02 \\
0.02\end{array}$ & $\begin{array}{r}98.56 \\
12.32 \\
0.05 \\
0.11\end{array}$ & $\begin{array}{r}86.48 \\
1.28 \\
0.00 \\
0.00\end{array}$ & $\begin{array}{r}93.80 \\
6.05 \\
0.03 \\
0.06\end{array}$ \\
\hline 2.Chd & $\begin{array}{l}\Lambda \mathrm{u} \\
\Lambda \mathrm{g} \\
\mathrm{Cu} \\
\mathrm{Hg}\end{array}$ & & $\begin{array}{r}53.58 \\
17.04 \\
0.00 \\
0.00\end{array}$ & & $\begin{array}{r}76.98 \\
36.96 \\
0.08 \\
0.15\end{array}$ & $\begin{array}{r}61.47 \\
24.39 \\
0.00 \\
0.00\end{array}$ & $\begin{array}{r}68.44 \\
30.42 \\
0.03 \\
0.03\end{array}$ & $\begin{array}{r}100.00 \\
7.67 \\
0.08 \\
0.18\end{array}$ & $\begin{array}{r}91.36 \\
0.10 \\
0.00 \\
0.00\end{array}$ & $\begin{array}{r}96.47 \\
2.87 \\
0.04 \\
0.02\end{array}$ \\
\hline 3.LCu & $\begin{array}{l}\mathrm{Au} \\
\mathrm{Ag} \\
\mathrm{Cu} \\
\mathrm{Hg}\end{array}$ & $\begin{array}{r}80.89 \\
35.81 \\
0.13 \\
0.20\end{array}$ & $\begin{array}{r}62.79 \\
20.43 \\
0.00 \\
0.00\end{array}$ & $\begin{array}{r}71.72 \\
27.20 \\
0.03 \\
0.05\end{array}$ & $\begin{array}{r}80.89 \\
27.48 \\
0.09 \\
0.28\end{array}$ & $\begin{array}{c}71.49 \\
20.37 \\
0.00 \\
0.00\end{array}$ & $\begin{array}{r}75.82 \\
23.44 \\
0.05 \\
0.11\end{array}$ & $\begin{array}{r}99.49 \\
12.90 \\
0.09 \\
0.89\end{array}$ & $\begin{array}{r}86.11 \\
0.07 \\
0.00 \\
0.00\end{array}$ & $\begin{array}{r}96.57 \\
2.41 \\
0.05 \\
0.16\end{array}$ \\
\hline 4. $1 \mathrm{~cm}$ & $\begin{array}{l}\mathrm{Au} \\
\mathrm{Ag} \\
\mathrm{Cu} \\
\mathrm{Hg}\end{array}$ & $\begin{array}{r}76.88 \\
32.33 \\
0.07 \\
0.11\end{array}$ & $\begin{array}{r}67.19 \\
23.38 \\
0.00 \\
0.00\end{array}$ & $\begin{array}{r}73.94 \\
25.59 \\
0.02 \\
0.02\end{array}$ & $\begin{array}{r}75.10 \\
32.15 \\
0.08 \\
0.11\end{array}$ & $\begin{array}{r}67.68 \\
23.79 \\
0.01 \\
0.00\end{array}$ & $\begin{array}{r}71.27 \\
27.84 \\
0.04 \\
0.03\end{array}$ & $\begin{array}{r}98.74 \\
1.70 \\
0.08 \\
0.15\end{array}$ & $\begin{array}{r}96.90 \\
0.49 \\
0.01 \\
0.00\end{array}$ & $\begin{array}{r}98.12 \\
1.10 \\
0.05 \\
0.05\end{array}$ \\
\hline 5.Rgu & $\begin{array}{l}\mathrm{Au} \\
\mathrm{Ag} \\
\mathrm{Cu} \\
\mathrm{Hg}\end{array}$ & $\begin{array}{r}82.94 \\
44.52 \\
0.09 \\
0.14\end{array}$ & $\begin{array}{r}52.33 \\
14.97 \\
0.00 \\
0.00\end{array}$ & $\begin{array}{r}67.67 \\
31.18 \\
0.03 \\
0.01\end{array}$ & $\begin{array}{r}77.90 \\
46.48 \\
0.07 \\
0.19\end{array}$ & $\begin{array}{r}52.33 \\
23.76 \\
0.00 \\
0.00\end{array}$ & $\begin{array}{r}66.87 \\
33.37 \\
0.02 \\
0.03\end{array}$ & $\begin{array}{r}100.00 \\
17.56 \\
0.21 \\
0.12\end{array}$ & $\begin{array}{r}83.50 \\
0.31 \\
0.00 \\
0.00\end{array}$ & $\begin{array}{r}92.95 \\
7.80 \\
0.05 \\
0.02\end{array}$ \\
\hline 6.Cpm & $\begin{array}{l}\mathrm{Au} \\
\mathrm{Ag} \\
\mathrm{Cu} \\
\mathrm{Hg}\end{array}$ & $\begin{array}{r}78.83 \\
37.63 \\
0.09 \\
0.20\end{array}$ & $\begin{array}{r}60.42 \\
20.32 \\
0.00 \\
0.00\end{array}$ & $\begin{array}{r}71.19 \\
26.52 \\
0.03 \\
0.03\end{array}$ & $\begin{array}{r}74.36 \\
34.04 \\
0.04 \\
0.15\end{array}$ & $\begin{array}{r}64.70 \\
24.09 \\
0.00 \\
0.00\end{array}$ & $\begin{array}{r}69.38 \\
28.93 \\
0.01 \\
0.05\end{array}$ & $\begin{array}{r}100.00 \\
3.51 \\
0.13 \\
0.15\end{array}$ & $\begin{array}{r}91.29 \\
0.28 \\
0.00 \\
0.00\end{array}$ & $\begin{array}{r}97.23 \\
1.47 \\
0.04 \\
0.02\end{array}$ \\
\hline
\end{tabular}

Sampling sites 1 to 6 are shown in Figure 1. Symbols: CH: Arroyo Cañada Honda LC: Río de La Carpa: RG: Río Grande; CP: Creek at foothills, Cerro de Piedra; upstream; d: downstream: m: middle strean; Max: maximum; Min: minimum; Av: appearance at the margins of some rimless grains.

TABL.E. 5. MAXIMUM, MINIMUM AND AVERAGE CONCENTRATIONS OF $\Lambda \mathrm{u}, \Lambda \mathrm{g}, \mathrm{Cu}$ AND $\mathrm{Hg}$ IN Hg-CONTAMINATLID GOLD GRAINS,

\begin{tabular}{|c|c|c|c|c|c|c|}
\hline \multirow[t]{2}{*}{ Site } & \multirow[t]{2}{*}{ Elem. } & \multirow{2}{*}{$\frac{\text { Core }}{\text { Max. }}$} & \multirow{2}{*}{\begin{tabular}{c} 
Border \\
\hdashline$\cdots-$ \\
Max.
\end{tabular}} & \multicolumn{3}{|c|}{$\operatorname{Rim}$} \\
\hline & & & & Max. & Min. & $\Lambda v$. \\
\hline 3.LCu & $\begin{array}{l}\text { Au } \\
\mathrm{Ag} \\
\mathrm{Cu} \\
\mathrm{IIg}\end{array}$ & $\begin{array}{r}78.76 \\
4.82 \\
0.03 \\
14.43\end{array}$ & $\begin{array}{r}55.59 \\
26.76 \\
0.08 \\
14.86\end{array}$ & $\begin{array}{r}72.64 \\
23.07 \\
0.05 \\
24.87\end{array}$ & $\begin{array}{r}53.86 \\
7.67 \\
0.00 \\
19.66\end{array}$ & $\begin{array}{r}61.67 \\
15.71 \\
0.03 \\
22.17\end{array}$ \\
\hline 4. $\mathrm{LCm}$ & $\begin{array}{l}\mathrm{Au} \\
\mathrm{Ag} \\
\mathrm{Cu} \\
\mathrm{Hg}\end{array}$ & $\begin{array}{l}\text { n.d. } \\
\text { n.d. } \\
\text { n.d. } \\
\text { n.d. }\end{array}$ & $\begin{array}{r}54.84 \\
19.95 \\
0.01 \\
25.21\end{array}$ & $\begin{array}{r}62.10 \\
14.05 \\
0.05 \\
30.89\end{array}$ & $\begin{array}{r}55.06 \\
12.26 \\
0.01 \\
21.22\end{array}$ & $\begin{array}{r}58.58 \\
13.16 \\
0.03 \\
26.06\end{array}$ \\
\hline $5 . R G u$ & $\begin{array}{l}\mathrm{Au} \\
\mathrm{Ag} \\
\mathrm{Cu} \\
\mathrm{IIg}\end{array}$ & $\begin{array}{r}93.76 \\
5.59 \\
0.00 \\
1.64\end{array}$ & $\begin{array}{r}61.51 \\
37.46 \\
0.02 \\
2.49\end{array}$ & $\begin{array}{r}91.88 \\
42.16 \\
0.06 \\
11.54\end{array}$ & $\begin{array}{r}53.83 \\
4.30 \\
0.00 \\
1.64\end{array}$ & $\begin{array}{r}75.14 \\
19.41 \\
0.03 \\
5.76\end{array}$ \\
\hline
\end{tabular}

Sampling siles 3, 4, 5 are shown in Figure 1; LC: Rio de La Carpa; RG: Río Grande u: upstream; m: middle stream; Max: maximum; Min: minimum; Av: Average; n,d. performed where we found a difference in the apperance "Border analyses" were rimless grains. Compositions are reported in wt $\%$. 
TABLE 6. SUMMARY OF NEARBY SOURCES OF MINERALIZATION, SAN LUIS RANGE,

\begin{tabular}{|c|c|c|c|c|c|c|}
\hline Lode deposit: & Deposit type & Host rock & Mineral suite & $\Lambda \mathrm{ug} / \mathrm{t}$ & Au fineness & Reference \\
\hline La Carolina & $\begin{array}{l}\text { Epithermal } \\
\text { veins }\end{array}$ & $\begin{array}{l}\text { Schist, } \\
\text { gneiss }\end{array}$ & $\begin{array}{l}\text { Au-rich py, } \\
\mathrm{Au}, \mathrm{sp}, \mathrm{gn}\end{array}$ & Up to 4 & No data & Angelelli (1984) \\
\hline La Esstancia & $\begin{array}{l}\text { Epithermal } \\
\text { veins }\end{array}$ & $\begin{array}{l}\text { Gneiss, } \\
\text { quartzite, } \\
\text { mylonite }\end{array}$ & $\begin{array}{l}\text { py, gn, sp, mc, } \\
\text { cp, Au-Ag } \\
\text { alloy, Au }\end{array}$ & 4.6 & $\begin{array}{l}670 \text { for } \mathrm{Au}-\mathrm{Ag} \\
\text { alloy; no data } \\
\text { for } \mathrm{Au}\end{array}$ & $\begin{array}{l}\text { Márquez-Zavalía } \\
\text { \& Galliski (1994) }\end{array}$ \\
\hline La Rica & $\begin{array}{l}\text { Epithermal } \\
\text { veins }\end{array}$ & $\begin{array}{l}\text { Schist, } \\
\text { gneiss }\end{array}$ & $\begin{array}{l}\text { Au-rich py, } \\
\text { apy, Au }\end{array}$ & 0.2 to 2 & No data & $\begin{array}{l}\text { Rosello \& } \\
\text { Castro (1995) }\end{array}$ \\
\hline La Juana & $\begin{array}{l}\text { Veins } \\
\text { (epithermal?) }\end{array}$ & Andesite & $\begin{array}{l}\text { Au-rich py, } \wedge \mathrm{u} \\
\text { sp, gn, (apy?) }\end{array}$ & No data & No data & $\begin{array}{l}\text { Rosello \& } \\
\text { García (1983) }\end{array}$ \\
\hline La Carpa & $\begin{array}{l}\text { Veins } \\
\text { (epithermal?) }\end{array}$ & Gneiss & Au-rich py & No data & No data & $\begin{array}{l}\text { Roscllo \& } \\
\text { García (1983) }\end{array}$ \\
\hline
\end{tabular}

Symbols: py: pyrite, sp: sphalcrite, gn: galena, mc: marcasite, cp: chalcopyritc, apy: arsenopyrite.

grains (Knight et al. 1999b). There is also a tendency toward enrichment of the minimum fineness of the core (Table 2) from the three sampling sites to the west (3.LCu, 4.LCm and 6.CPm) compared with placer gold sampled eastward (1.CHu, 2.CHd and 5.RGu).

The average Au content of the core, 58-74 wt.\%, indicates that the source(s) that supplied the material had gold of a low fineness. The variable and broad range of fineness of the gold grains found in the area is typical of low-sulfidation epithermal-type deposits (Morrison et al. 1991). This suggestion agrees with the composition of gold particles described from a primary gold-bearing deposit in the area, La Estancia at (Fig. 1), a lowsulfidation epithermal-type deposit characterized by coexistence of $\mathrm{Au}-\mathrm{Ag}$ alloy and gold; the former predominates and has an average fineness of 670 (MárquezZavalía \& Galliski 1994).

In the study area, there are several small epithermal deposits, such as La Carolina, La Estancia and La Rica mines, and possibly La Juana and La Carpa mines (Fig. 1, Table 6). The La Carolina mine is located near sampling site 5.RGu, La Estancia and La Rica mines are nearer sampling site $1 . \mathrm{CHu}$, whereas the other two mines, La Juana and La Carpa, are located between sampling sites 3.LCu and 4.LCm. In the area, there are also several linear zones of alteration, where the disseminated mineralization consists of gold and silver associated mainly with pyrite; one sample of pyritic schist gave $1 \mathrm{~g} \mathrm{Au} / \mathrm{t}, 2 \mathrm{~g} \mathrm{Ag} / \mathrm{t}$ and traces of As (Bassi 1990). We are not aware of any other epithermal-type deposit in this area; using the Klondike placers as an analogy (see Knight et al. 1999b), however, we concede that some occurrences may be either unexposed at present or have been erosionally stripped. Unfortunately, there are no values of fineness of gold available from any of the mines except La Estancia.

Even if grain morphology is generally a less reliable indicator of provenance than fineness (Grant et al. 1991), or at least not a sufficient argument for deter- mining the existence of multiple sources, we know of the existence of several gold deposits in the area (Fig. 1, Table 6) and at least some must have supplied the gold, if not all of them. In the La Estancia epithermal-type deposit (Fig. 1), fine-grained (1-10 $\mu \mathrm{m})$, pure gold and the more abundant and coarser $(10-100 \mu \mathrm{m})$ irregular grains of $\mathrm{Au}-\mathrm{Ag}$ alloy coexist. Besides, an interpretation of multiple sources may indicate as well, according to Giusti \& Smith (1984), that either the gold is derived from different areas, or that gold of different compositions was derived from a single deposit with gold derived from more than one stage of emplacement. Suffice it to say, all the sources are restricted to the deposits from Tertiary igneous rocks in the area (see also Bassi 1948, Rosello \& Castro 1995).

Finally, in one sample (6.CPm), we found rounded grains of gold together with one crystal of petzite with some of its crystal faces still perfectly preserved. This fact also suggests multiple sources for the material, because petzite is both soft (hardness 2.5-3) and brittle, so that any significant transportation would obliterate its crystal faces.

\section{Formation of the rim}

The $\mathrm{Au}$ and $\mathrm{Ag}$ values of the core and rim of grains collected in the two streams with upstream and downstream depositional affinities (Arroyo Cañada Honda: 1.CHu and 2.CHd, and Río de La Carpa: 3.LCu and 4.LCm; Fig. 1, Table 4) suggest that the Au-rich compositions in the rim possibly reflect a combination of distance and duration of transport (Fig. 7). Evidence for progressive growth of the gold grains with transportation is indicated by the fact that those grains collected upstream generally lack a rim, whereas grains sampled further downstream generally have a rim, even if it is discontinuous (Table 1). Together with observations of grain-growth in placer gold in New Zealand (Craw \& Youngson 1993, Youngson \& Craw 1993, 1995), this 

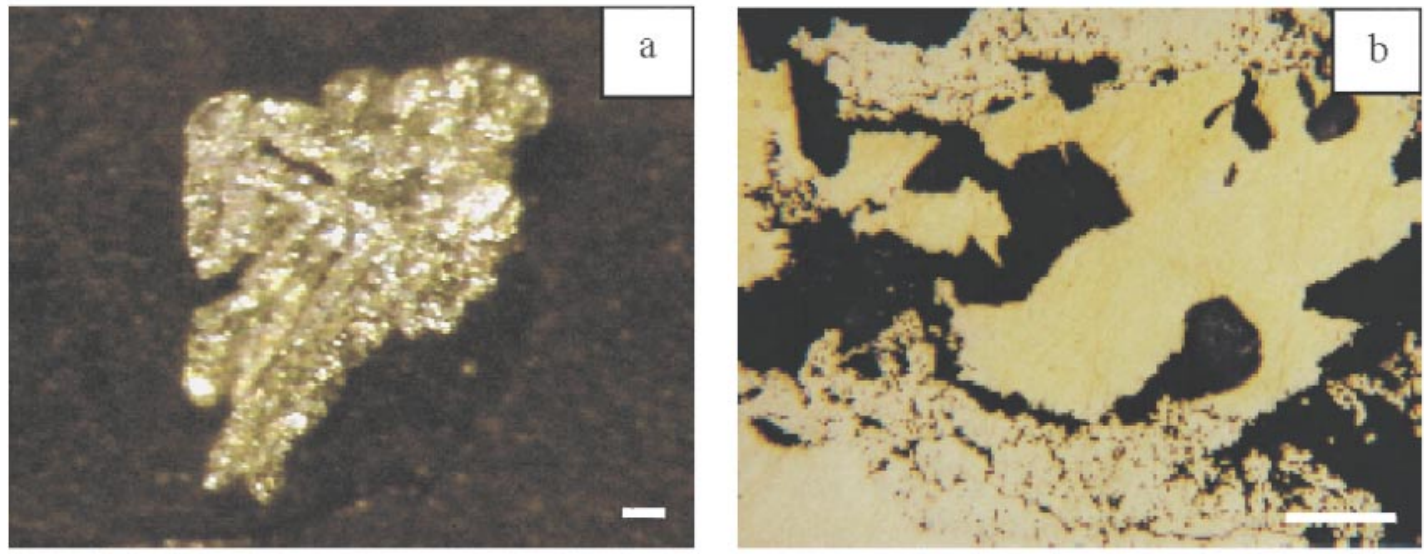

FIG. 4. Typical morphology of gold grains recovered from site 3.LCu; scale bar: $100 \mu \mathrm{m}$. (a) Aggregates of arborescent gold crystals. (b) Rim with "brain-like" appearance containing high $\mathrm{Hg}$ contamination $(16.25 \% \mathrm{Hg})$, and inclusions of quartz.
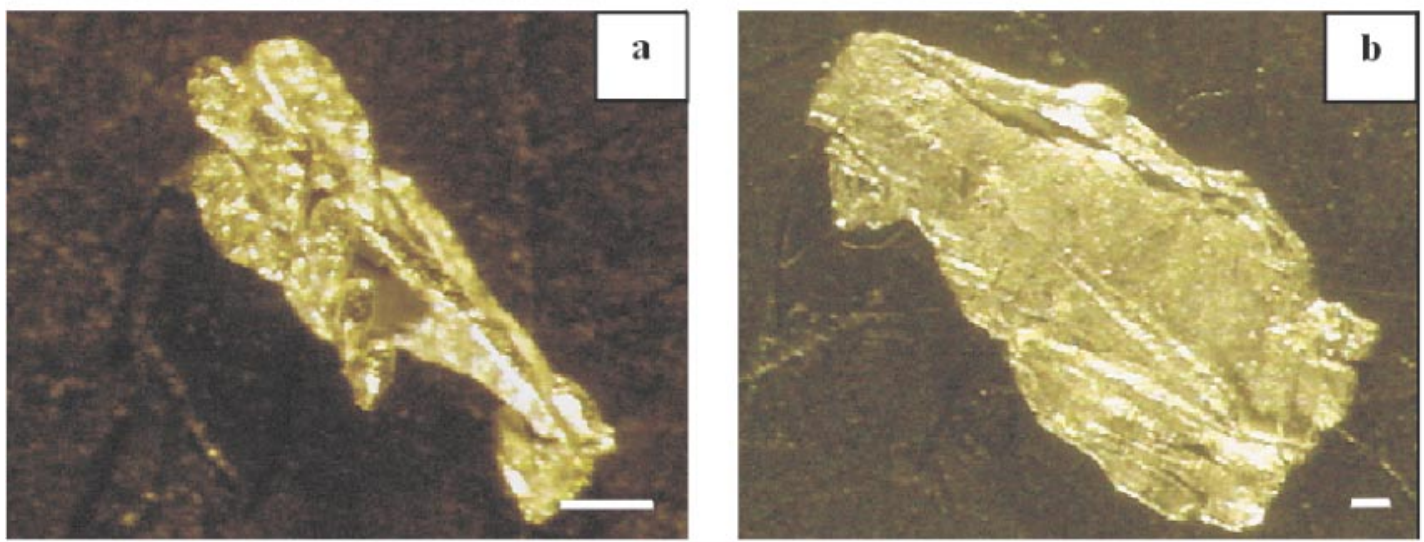

Fig. 5. Typical morphology of gold grains recovered from site 4.LCm; scale bar: $300 \mu \mathrm{m}$. (a) Aggregates of arborescent gold crystals. (b) Leaf of gold with folded tip.

phenomenon may reflect the overall process: the further the gold grain is transported downstream, the more enriched the rim becomes, the greater the proportion of the grains that possess a rim, and the thicker the rim becomes.

Gold grains recovered from the downstream sites Arroyo Cañada Honda (2.CHd) and Río de La Carpa (4.LCm) are generally depleted in silver in their core and rim. We attribute this to enrichment of gold in the rim during rim accretion and possibly to selective leaching of Ag either during transport or even after deposition.

In some cases, we observed thin "veins" that locally penetrate and dissect some of the grains along fractures or cracks; these veins have compositions different from the core, and generally they are also distinct from rim compositions. These veins, also described by Robinson et al. (1999), may result from precipitation of gold in open fissures in gold grains, either during transportation or after deposition in the placer, unless they represent a region where two or more smaller grains of gold were "glued" together. Hence, the mechanism that produces a rim (Craig \& Callahan 1989) and the one forming these veins may have similarities.

The contact between core and rim is invariably very sharp, and may result from electrochemical processes active either in the stream or in the stream sediments (Mann 1984, Groen et al. 1990, Krupp \& Weiser 1992, Knight et al. 1999a), or from processes of dissolution of gold and silver followed by gold precipitation in sur- 

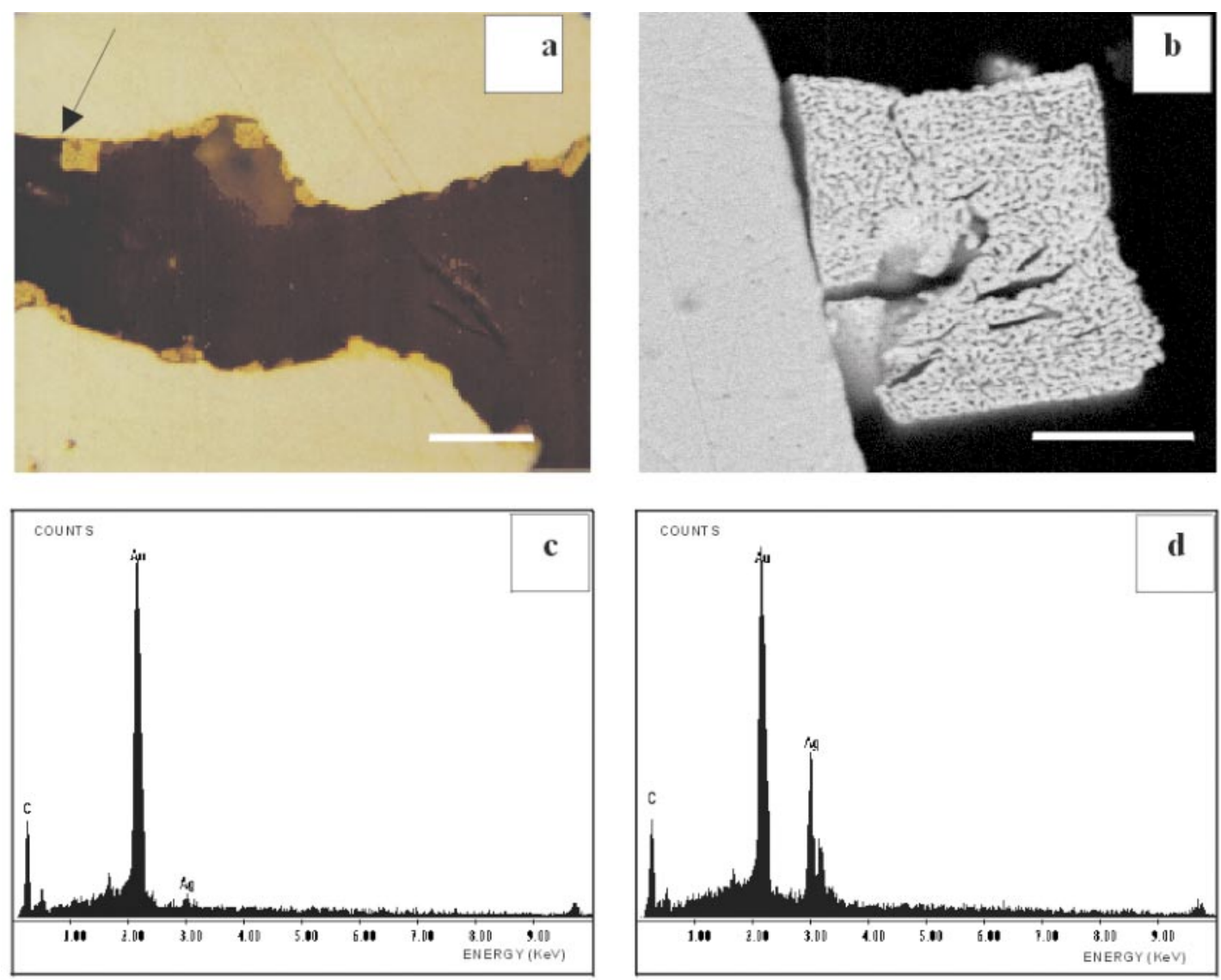

FIG. 6. a. A grain of gold from sampling site 5.RGu possessing unusual cubic-section crystals, occurring along the margins. (b) Back-scattered FEG-SEM micrograph of the cubic grain observed in (a). Note the porous, submicrometric sponge-like texture of the cubic mineral phase. (c) The FEG-SEM-EDS spectrum of the cubic crystal [see arrow in (a)] demonstrates that it is composed of gold, whereas (d) the border region (within the gold grain), is composed of gold and silver. Scale bars equal $100 \mu \mathrm{m}$ and $5 \mu \mathrm{m}$ in (a) and (b), respectively.

face and near-surface environments (Wilson 1984, Groen et al. 1990, Southam 1998). We consider the latter model more likely because electrochemical leaching of $\mathrm{Ag}$ would most likely produce a regular rim rather than the discontinuous rim observed (Figs. 2b, c). The presence of a discontinuous rim is also considered to occur in active abrasive sediments (Knight et al. 1999a). The rim may also exhibit an irregular shape and a complex texture, which might be a result of solid-state reactions rather than deposition from solution, with the reaction front moving inward, at different rates in different directions and locations (Robinson et al. 1999).

\section{Formation of secondary gold}

Several samples from Cañada Honda (2.CHd) possess overgrown gold crystals over gold grains (e.g., Fig. 3d), suggesting that secondary precipitation of gold had occurred only after the host grain was formed. In a Brazilian placer system, secondary crystals of gold were recovered by gravity separation several years after placer mining had recovered rounded grains, indicating that the new secondary gold had formed either in situ after mining or had been transported into this system from a nearby source (Freise 1931).

The cubic habit of gold shown in Figure $6 a$ and $6 b$ represents an unusual development of secondary gold that presumably resulted as a $\mathrm{Au}-\mathrm{Hg}$ amalgam (Desborough \& Foord 1992) from the Hg present in this system, followed by removal of $\mathrm{Hg}$, which was not detected by EDS analysis (Fig. 6c). The submicrometric structure of this porous, spongy gold is finer than that typically associated with the reaction of $\mathrm{Hg}$ with surfaces of grain grains which produce a "brain-like" ap- 
pearance (Fig. 4b; Knight 1993), but it is consistent with the $\leq 5 \mu \mathrm{m}$ monoclinic, pseudo-orthorhombic $\mathrm{Au}-\mathrm{Hg}$ mineral described by Desborough \& Foord (1992).

The presence of metal sulfides within some of the grains and local iron oxyhydroxide coating suggests a primarily oxidizing environment of weathering. The transformation of metal sulfides to iron oxyhydroxides is an indication that chemical and bio-oxidation of metal sulfides has either occurred or is still occurring in this placer system (Nordstrom \& Southam 1997). Furthermore, the formation of sulfoxyanions through either abiotic or biotic mechanisms (Schippers et al. 1999) could have contributed thiosulfate as an effective goldcomplexing agent to promote weathering and dissolution (Vlassopoulos \& Wood 1990), leading to formation of secondary gold. This weathering environment was undoubtedly aided by plant (Baker 1978, Bowell et al. 1993) and even bacterially derived organic phases (Korobushkina et al, 1974, 1976, Vlassopoulos et al. 1990, Southam \& Beveridge 1994, 1996) that would also have facilitated formation of secondary gold.

\section{Anthropogenic $\mathrm{Hg}$}

Where present, $\mathrm{Hg}$ is encountered mostly in the rims of the grains. However, two analyses performed in the core area gave high $\mathrm{Hg}$ values (1.6 and $14.4 \mathrm{wt} \% \mathrm{Hg}$ ). The composition of those grains, from sampling sites
5. $\mathrm{RGu}$ and 3. $\mathrm{LCu}$, respectively $(\mathrm{Au}, \mathrm{Ag}, \mathrm{Cu}, \mathrm{Hg}$ ) is: 93.76, 5.59, 0.00, 1.64 and 78.76, 4.82, 0.03, 14.43. For these compositions, we strongly believe that the rim was thick enough to still be covering the grain after the grinding and polishing process, and that they have the appearance of rimless grains.

We interpret all the $\mathrm{Hg}$ in the grains as being anthropogenic. Weishanite, $(\mathrm{Au}, \mathrm{Ag})_{1.2} \mathrm{Hg}_{0.8}$, the only IMAapproved mineral containing $\mathrm{Au}$ and $\mathrm{Hg}$, was not recognized in the samples. Even though there are numerous sources for anthropogenic mercury, such as fertilizers, medical compounds (antiseptics and diuretics), and some now-prohibited agricultural fungicides and herbicides (Meisser \& Brugger 2000), we believe that all the $\mathrm{Hg}$ identified here is from the amalgamation processes used to recover the gold.

The placer gold from the San Luis Range of Argentina is a good example of a natural environment that possesses a limited anthropogenic impact. In this environment, gold grains possessing a core of $\mathrm{Au}-\mathrm{Ag}$ alloy have become enriched in higher-fineness gold as a surface coating. The gold grains are also "glued" together to form larger grains (aggregates). Gold grains do grow in low-temperature geochemical settings but, more importantly, they become gold-enriched either by loss of silver or by loss of silver followed by reprecipitation of gold. The net effect, recognized long ago and confirmed here, is that the overall composition becomes more gold-
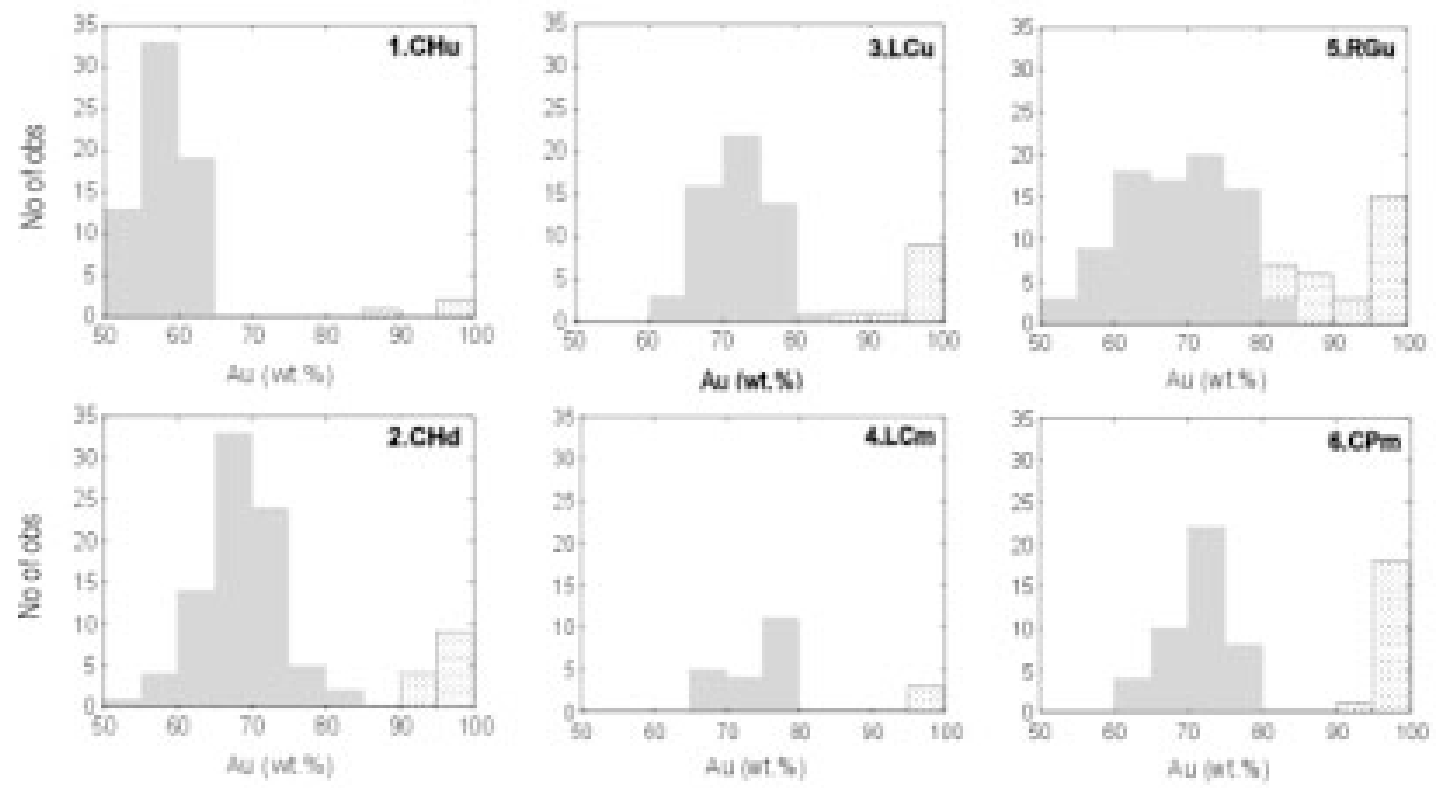

FIG. 7. Histograms of core (plain gray pattern) and rim (dotted gray pattern) compositions of gold grains collected from the six sampling sites: Arroyo Cañada Honda upstream (1.CHu) and downstream (2.CHd), Río de La Carpa upstream (3.LCu) and middle stream (4.LCm), Río Grande upstream (5.RGu) and Creek at the foothills of Cerro de Piedra, middle stream (6.Cpm). 
rich as the grains move downstream or sit in the sedimentary environment.

\section{ACKNOWLEDGEMENTS}

The authors are grateful to Petr Černý for the access to the electron-microprobe facilities at the Department of Geological Sciences, University of Manitoba, Winnipeg, Canada, to Ron Chapman, who trained MFMZ in the art and science of electron-microprobe analysis, and to Fidel Roig, Jr., for access to the camera with which most of the photographs were taken under the binocular microscope. The FEG-SEM-EDS analyses were performed with the technical assistance of Ross Davidson at Surface Science Western, University of Western Ontario. The data for this paper were acquired during an external fellowship given to one of the authors (MFMZ) by the Consejo Nacional de Investigaciones Cientificas y Técnicas (CONICET) de la República Argentina. The manuscript greatly benefitted from insightful reviews by A.R. Cabral, J.B. Knight and R.F. Martin.

\section{REFERENCES}

Angelelli, V. (1984): Yacimientos metalíferos de la República Argentina. CIC Buenos Aires 2, 448-450.

BAKER, W.E. (1978): The role of humic acid in the transport of gold. Geochim. Cosmochim. Acta 42, 645-649.

BASSI, H.G.L. (1948): Los aluviones auríferos de la zona "La Carolina - Río de La Carpa" (Provincia de San Luis). Rev. Asociación Geol. Argentina 3, 5-53.

(1990): The sierra alta de San Luis. A case of regmagenic control of gold mineralization. In Basement Tectonics (M.J. Rickard, H.J. Harrington \& P.R. Williams, eds.). Kluwer, Dordrecht, The Netherlands (211-222).

Bowell, R.J., Gize, A.P. \& Foster, R.P. (1993): The role of fulvic acid in the supergene migration of gold in tropical rain forest soils. Geochim. Cosmochim. Acta 57, 4179-4190.

Burmeister, C. (1934): El oro de la Sierra de San Luis. Rev. Minera 4, 65-79.

CAStro, L.N. (1999): Depósitos aluvionales auríferos de San Luis. In Recursos Minerales de la República Argentina (E.O. Zappettini, ed.). Inst. Geol. Rec. Min., SEGEMAR 35, 1867-1872.

CRaig, J.R. \& Callahan, J.E. (1989): Paleoplacer gold in the Lilesville sand and gravel deposits, North Carolina. Georgia Geol. Surv. Bull. 117, 121-141.

CRAw, D. \& Youngson, J.H. (1993): Eluvial gold placer formation on actively rising mountain ranges, Central Otago, New Zealand. Sedim. Geol. 85, 623-635.
Desborough, G.A. \& Foord, E.E. (1992): A monoclinic, pseudo-orthorhombic $\mathrm{Au}-\mathrm{Hg}$ mineral of potential economic significance in Pleistocene Snake River alluvial deposits of southeastern Idaho. Can. Mineral. 30, 1033-1038.

Erasmus, C.S., Sellschop, J.P.F. \& Watterson, J.I.W (1987): New evidence on the composition of mineral grains of native gold. Nucl. Geophys. 1, 1-23.

FREISE, F.W. (1931): The transportation of gold by organic underground solutions. Econ. Geol. 26, 421-431.

Giusti, L. \& Sмith, D.G.W. (1984): An electron microprobe study of some Alberta placer gold. Tschermaks Mineral. Petrogr. Mitt. 33, 187-202.

Grant, A.H., Lavin, O.P. \& Nichol, I. (1991): The morphology and chemistry of transported gold grains as an exploration tool. J. Geochem. Explor. 40, 73-94.

Groen, J.C., Craig, J.R. \& Rimstidt, D. (1990): Gold-rich rims formation on electrum grains in placers. Can. Mineral. 28, 207-228.

Guillou, J. \& CARDó, R. (1995): Exploración del placer aurífero Cerritos Blancos - Mundo Nuevo y La Alameda, San Luis. Argentina. V Congreso Nacional Geología Económica (San Juan, Argentina) 1, 12-22.

Karlsson, A. \& Porta, G. (1991): Mineralogía de aluviones auríferos de La Carolina, Provincia de San Luis, Argentina. VI Congreso Geológico Chileno 6, 684-687.

KAY, S.M. \& GoRdILlO, C.E. (1994): Pocho volcanic rocks and the melting of depleted continental lithosphere above a shallowly dipping subduction zone in the central Andes. Contrib. Mineral. Petrol. 117, 25-44.

KNIGHT, J.B. (1993): Preliminary evidence for the involvement of budding bacteria in the origin of Alaskan placer gold: comment. Geology 21, 279-280.

Morison, S.R. \& Mortensen, J.K. (1999a): The relationship between placer gold particle shape, rimming, and distance of fluvial transport as exemplified by gold from the Klondike District, Yukon Territory, Canada. Econ. Geol. 94, 635-648.

Mortensen, J.K. \& Morison, S.R. (1999b): Lode and placer gold composition in the Klondike District, Yukon Territory, Canada: implications for the nature and genesis of Klondike placer and lode gold deposits. Econ. Geol. 94, 649-664.

Korobushima, E.D., Chernyak, A.S. \& Mineev, G.G. (1974): Dissolution of gold by microorganisms and products of their metabolism. Mikrobiologiya 43, 9-54.

Mineev, G.G. \& Praded, G.P. (1976): Mechanism of the microbiological process of dissolution of gold. Mikrobiologiya 45, 535-538.

KRUPP, R.E., \& WeISER, T. (1992): On the stability of goldsilver alloys in the weathering environment. Mineral. Deposita 27, 268-275. 
LeICHT, W. (1982): California gold. Mineral. Rec. 13, 375-387.

MANN, A.W. (1984): Mobility of gold and silver in lateritic weathering profiles: some observations from Western Australia. Econ. Geol. 79, 38-49.

MÁrqueZ-Zavalía, M.F. \& Galliski, M.A. (1994): Mineralogía y paragénesis de 'La Estancia', un depósito epitermal de la Sierra de San Luis. Rev. Asociación Geol. Argentina 49, 39-47.

Meisser, N. \& Brugger, J. (2000): Alluvial native gold, tetraauricupride and $\mathrm{AuSn}_{2}$ from western Switzerland. Schweiz. Mineral. Petrogr. Mitt. 80, 291-298.

Morrison, G.W., Rose, W.J. \& SubHash, J. (1991): Geological and geochemical controls on the silver content (fineness) of gold in gold-silver deposits. Ore Geol. Rev. 6, 333364.

Nordstrom, D.K. \& Southam, G. (1997): Geomicrobiology of sulfide mineral oxidation. Rev. Mineral. 35, 361-390.

Pouchou, J.L. \& PichoiR. F. (1984): A new model for quantitative analysis. A. Application to the analysis of homogeneous samples. La Recherche Aérosp. 5, 47-65.

$\&$

(1985): "PAP" $(\phi \rho Z)$ correction procedure for improved quantitative microanalysis. In Microbeam Analysis (J.T. Armstrong, ed.). San Francisco Press, San Francisco, California (104-106).

Robinson, B., Parkes, T. \& Clark, M. (1999): Gold-rich zones in gold-silver grains. An unsolved mystery? In MINSA Mini-Symposium (W.U. Reimold \& M. Cloete, eds.). Silverton, Australia (117-119).

Rosello, E.A. \& García, H.H. (1983): Geología de la comarca del Cerro del Valle y sus manifestaciones auríferas adyacentes, Departameto Pringles, Provincia de San Luis. II Congreso Nacional Geología Económica (San Juan, Argentina) 2, 617-630.

$\&$

(1995): Consideraciones genéticas del oro detrítico de Cañada Honda, Carolina, San Luis, Argentina. V Congreso Nacional Geología Económica (San Juan, Argentina) 1, 95-108.

SCHIPPERS A., Rohwerder, T. \& SAND W. (1999): Intermediate sulfur compounds in pyrite oxidation: implications for bioleaching and biodepyritization of coal. Appl. Microbiol. Biotech. 52, 104-110.

Sims, J.P., Ireland, T.R., Camacho, A., Lyons, P., Pieters, P.E., Skirrow, R.G., Stuart-Smith, P.G. \& Miró, R. (1998): U-Pb, Th- $\mathrm{Pb}$ and Ar-Ar geochronology from the southern Sierras Pampeanas, Argentina: implications for the Paleozoic evolution of the western Gondwana margin.
In The Proto-Andean Margin of Gondwana (R.J. Pankhurst \& C.W. Rapela, eds.). Geol. Soc. London, Spec. Publ. 142, 259-281.

Skirrow, R.G., Stuart-Smith, P.G. \& Lyons, P. (1997): Informe geológico y metalogénico de las Sierras de San Luis y Comechingones (provincias de San Luis y Córdoba) 1:250.000. Inst. Geol. Rec. Min., SEGEMAR, Anales 28.

Southam, G. (1998): Quantification of sulfur and phosphorus within secondary gold rims on Yukon placer gold. Geology 26, 339-342.

\& BEVERIDGE, T.J. (1994): The in vitro formation of placer gold by bacteria. Geochim. Cosmochim. Acta 58, 4527-4530.

$\&$ (1996): The occurrence of bacterially derived sulfur and phosphorus within derived crystalline and pseudocrystalline octahedral gold formed in vitro. Geochim. Cosmochim. Acta 60, 4369-4376.

Steenken, A., López de Luchi, M.G., Siegesmund, S. \& WeMmer, K. (2002): An insight into the structural evolution of the sierra de San Luis (southeastern Sierras Pampeanas, Argentina): a progress report. In XV Congreso Geol. Argentino (N. Cabaleri, C.A. Cingolani, E. Linares, M.G. López de Luchi, H.A. Ostera \& H.O. Panarello, eds.). CD-ROM, Art. $\mathrm{N}^{\circ} 373$.

URbina, N.P., SRuoga, P. \& Malvicini, L. (1997): Late Tertiary gold-bearing volcanic belt in the Sierras pampeanas of San Luis, Argentina. Int. Geol. Rev. 39, 287-306.

Vlassopoulos, D. \& Wood, S.A. (1990): Gold speciation in natural waters. I. Solubility and hydrolysis reactions of gold in aqueous solution. Geochim. Cosmochim. Acta 54, 3-12.

\& MucCI, A. (1990): Gold speciation in natural waters. II. The importance of organic complexing experiments with some simple model ligands. Geochim. Cosmochim. Acta 54, 1575-1586.

WiLsON, A.F. (1984) Origin of quartz-free gold nuggets and supergene gold found in laterites and soils - a review and some new observations. Aust. J. Earth Sci. 31, 303-316.

YoungSON, J.H. \& CRAw, D. (1993): Gold nugget growth during tectonically induced sedimentary recycling, Otago, New Zealand. Sedim. Geol. 84, 71-88.

$\&$ (1995): Evolution of placer gold deposits during regional uplift, central Otago, New Zealand. Econ. Geol. 90, 731-745.

Received April 19, 2003, revised manuscript accepted November 12, 2003. 